\title{
A Hundred Years of Gold Refining and Fabrication
}

\author{
DEGUSSA CELEBRATES ITS CENTENARY
}

To mark the occasion of its hundredth anniversary, the famous firm of Degussa of Frankfurt-am-Main has compiled a full account of its history, from the inception in 1873, through the difficult years of two world wars and on to the more recent growth of this leading member of the precious metals industry.

Founded on the basis of gold refining, the company still plays a leading part in this field as well as in the production of gold in the many manufactured and semi-manufactured forms required by industry, although in more recent years the fabrication of silver and of the platinum metals, as well as the production of a wide range of chemicals, have also been major activities.

The story of the growth of a small family business into a world-wide organisation begins even before the official foundation of the company. More than thirty years earlier, in 1841, a professional assayer, Friedrich Ernst Roessler, came from Darmstadt to take up an appointment as warden of the mint then operated by the Free City of Frankfurt-amMain. Two years later the City Council decided to lease to him the plant and buildings of the gold refinery associated with the mint, these to be operated in future for his personal account while he continued to be responsible to them for the actual minting of

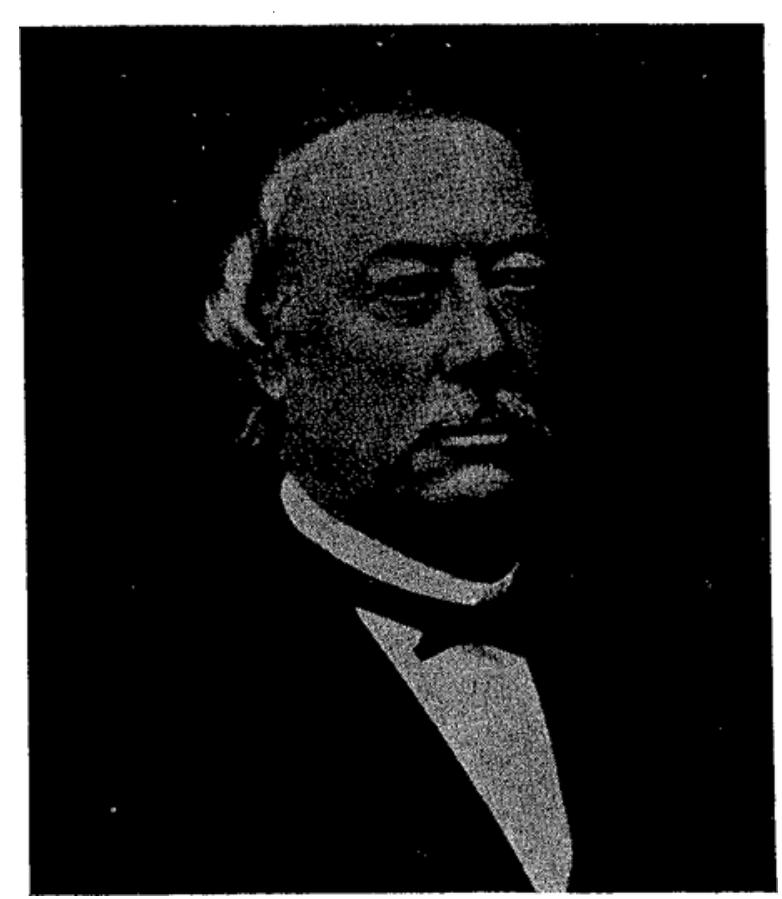

coin. The minutes recording this unusual division of responsibility describe Roessler as "a man whose reputation and credit leave nothing to be desired" and go on, in reference to the refining business, that "such activities are always operated with more enthusiasm and success for the account of private persons rather than by nationalised undertakings".

One of Roessler's first ventures in extending the scope of his refinery was the production of copper sulphate, but by 1860 he found that limitations of space would not allow for further expansion and he established a small chemical works on a plot of land he had bought for this purpose-a plot still identifiable in the heart of the company's headquarters complex in Frankfurt. Three years later he transferred this new business to his eldest son Hector, then 21 years old and a graduate of the Mining Academy of Freiburg.

In the meantime the refinery prospered, handling substantial quantities of demonetised coin, and Frankfurt became established as a major source of gold and silver supplies, while refining profits increased and were ploughed back into the business. But the incorporation in 1866 of the Free City of Frankfurt into the Kingdom of Prussia brought to an end Roessler's dual role as an officer of the mint and at the same time a private refiner. In the following year, therefore, wishing to remain as warden of the mint, he transferred the refinery business to his two elder sons Hector and Heinrich, he himself staying in the service of Prussia until his retirement at the age of 60 in 1873. Six years later the Frankfurt mint was closed down.

\section{Friedrich Ernst Roessler 1813-1883}

Master of the mint operated by the Free City of Frankfurt, Roessler was invited by the City Council in 1843 to take over for his own account the associated refining activities while continuing in his official capacity. From this beginning stemmed the formation in 1873 of the company now known as Degussa 
In the hundredth year of its existence Degussa has com. pleted the building of a new gold refinery. Here finished cathodes are being lifted from one of the electrolytic cells

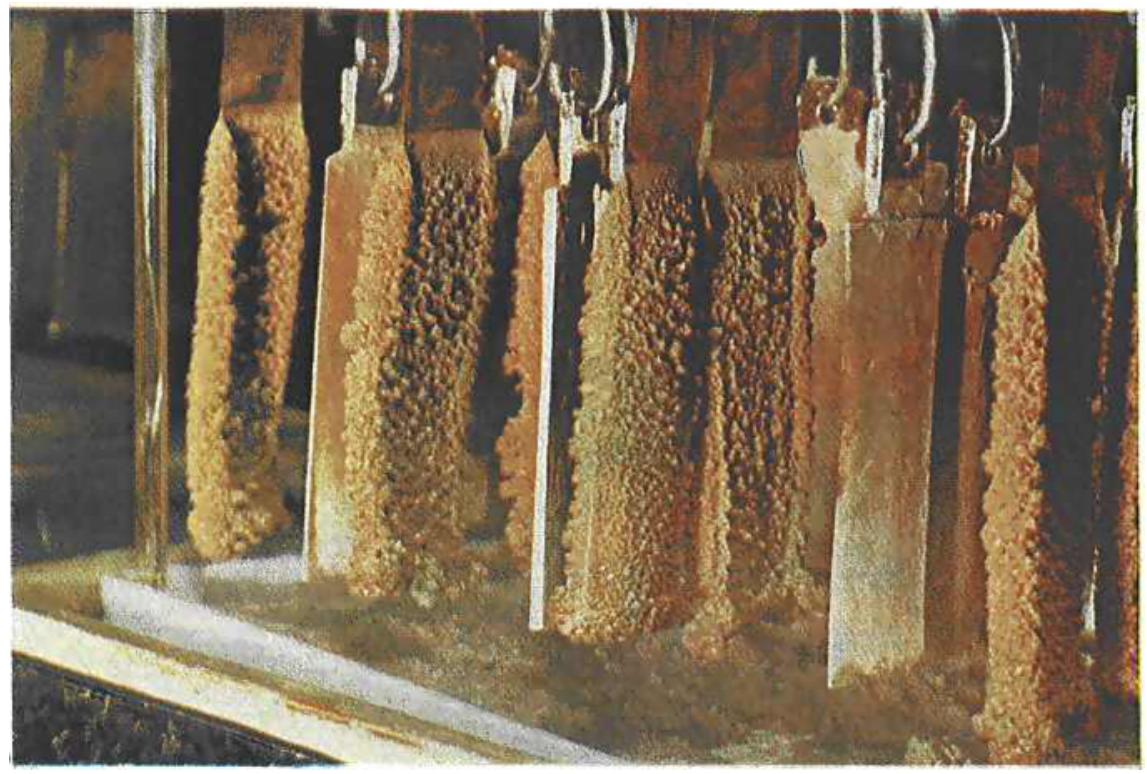

The refinery, together with Hector's small chemical business, was now established under the name of Friedrich Roessler Söhne. Like his brother, Heinrich had studied at the Mining Academy at Freiburg, and later taken his doctor's degree in chemistry under the great Professor Wöhler at Göttingen. Now, aged

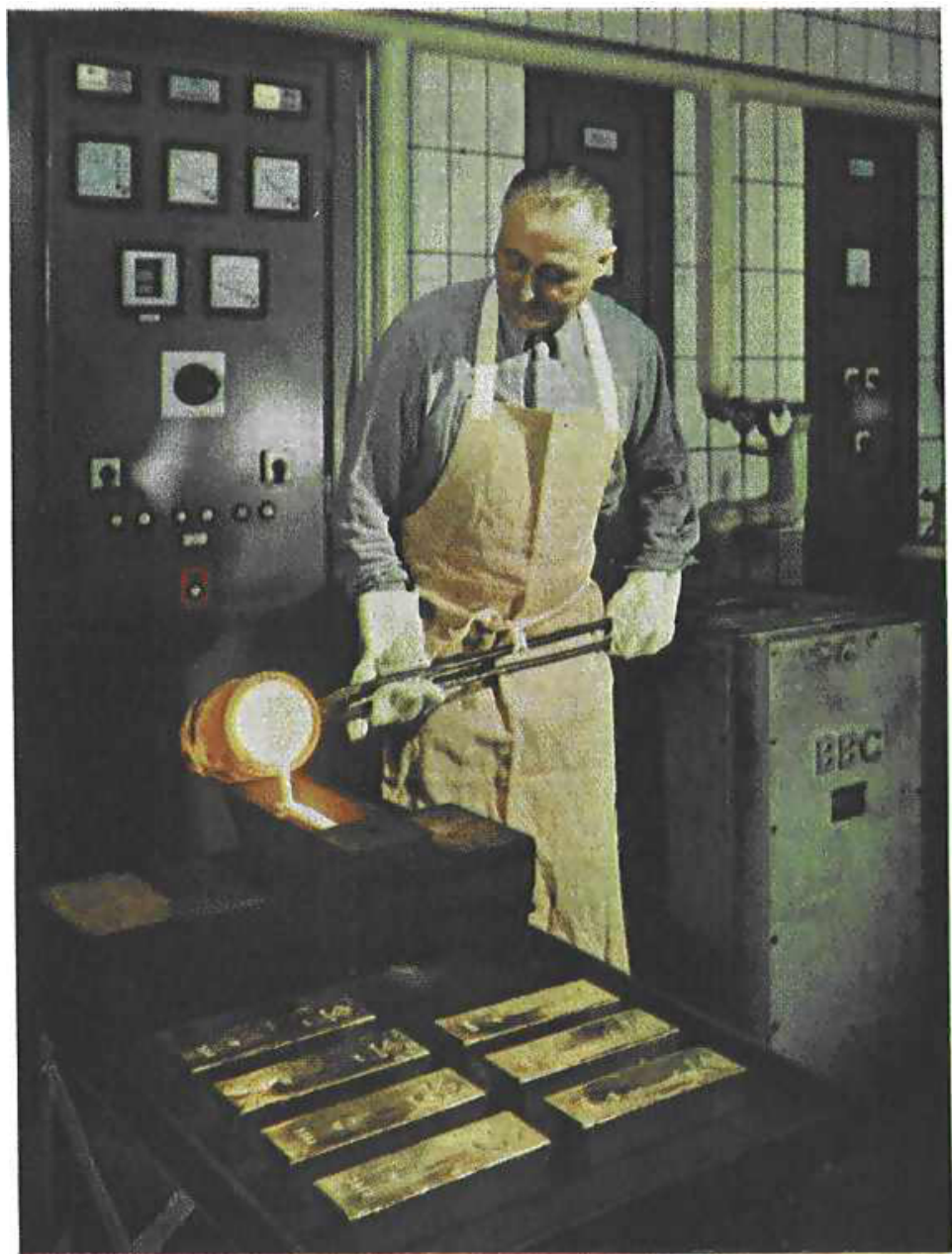

22, he took charge of the refinery, leaving Hector to take care of the chemical side of the operations, and at once began to seek further business, particularly in the refining of low grade silver containing small amounts of gold from the lead mines in the Rhineland. In the course of his business travels he made the acquaintance of the firm Philipp Abraham Cohen, Sonderheim, who were also interested in acquiring the same type of refinable material, and it was at the suggestion of the partners in this concern that the Roessler brothers came to the conclusion that they must-in the interest of further growth-convert their business into a limited company. They were further encouraged in this view by the requirement of fine gold now developing for the preparations used for the decoration of pottery. It was also their father's wish that the Darmstadt Bank and certain of their allied banking houses should be associated with the new company.

And so, on January 31st, 1873, the Deutsche Gold-und Silber-ScheideAnstalt vormals Roessler was officially constituted, this company incorporating

Casting ingots of fine gold in the new refinery that has just been put into commission at Wolfgang 


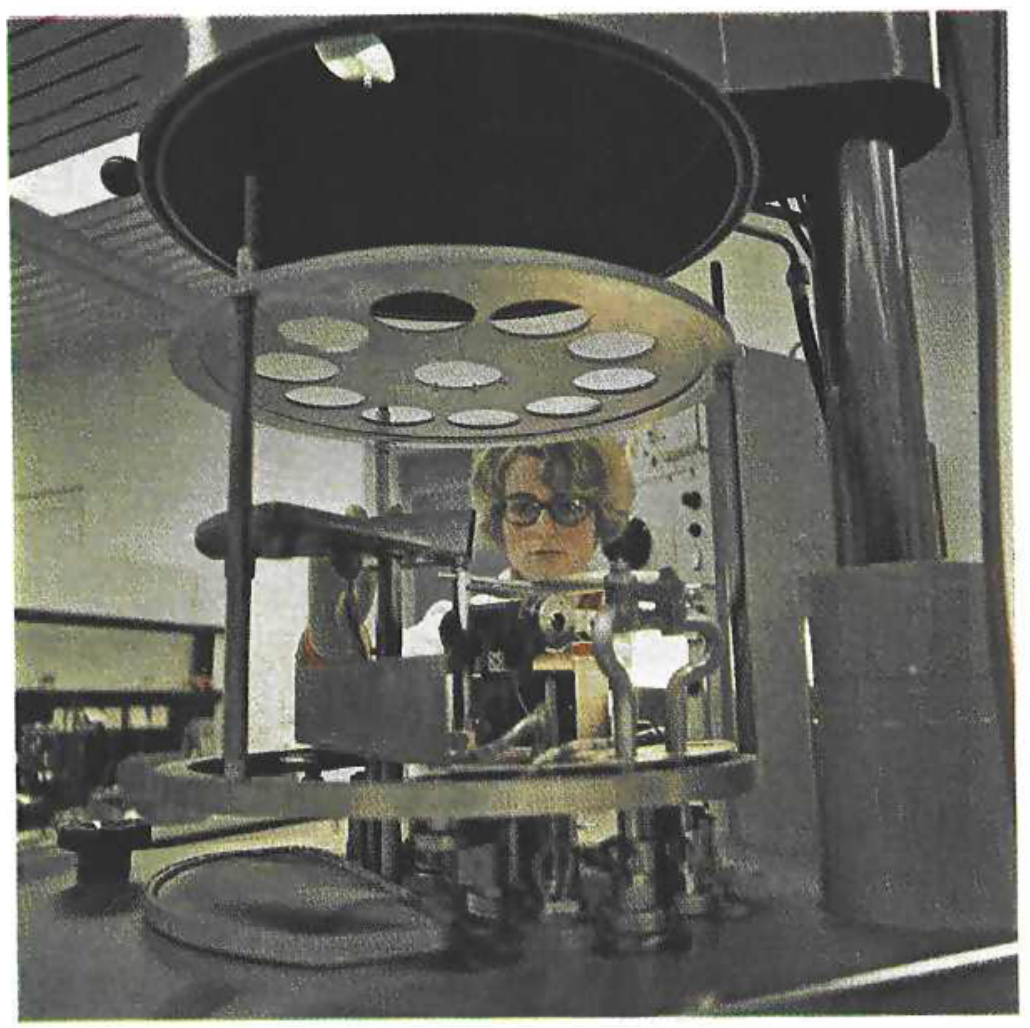

Research into the applications of gold in industry is one feature of the new laboratories recently opened at Wolfgang. This electron beam evaporation apparatus is used for investigations in the deposition of gold on to plastics, glass and a wide range of ceramic substrates

By the turn of the century great expansion had taken place in the chemical activities-including the production of sodium cyanide for the newly developed gold mines in the Transvaal-and the first steps had been taken into the organics field. The rapidly growing business needed more and more capital and several times new issues had to be arranged.

The first world war, followed by the disastrous inflation in Germany, laid extremely heavy burdens on the organisation, and it was almost a new start that

the existing refining operations of Friedrich Roessler Söhne, the chemicals business (mainly gold and silver salts, cyanides and also a number of pharmaceutical products) of Hector's laboratory, together with the precious metal trading activities of the Cohen company, with the bank as the major shareholder.

The first board of directors consisted only of the brothers Hector, then 31, and Heinrich aged 28, both essentially technical men, the elder rather quiet and retiring, the younger showing greater initiative and acting as spokesman, and it was not until six years later-six highly successful years of massive contracts for the refining of coinage and the supply of fine gold and silver-that it was thought desirable to appoint a commercial member to the board of directors. Hugo Andreae, then aged only 25, who had made an impression by a successful visit to secure business from the government of Italy, was appointed in 1879 , to be followed nine years later by Alexander Schneider, who had equally distinguished himself in developing the chemical side of the business.

It was these four men, Hector and Heinrich Roessler, Andreae and Schneider, who laid the foundations of today's international enterprise, while the younger sons of old Friedrich also played their parts in establishing subsidiaries or branchesBernhard and Julius in Berlin, Louis in Vienna and Franz in New York. had to be made in the early twenties. Under the leadership of Dr Ernst Busemann, however, the company again expanded its activities and increased in stature. Additional productive capacity was soon needed for the fabrication of gold, silver and the platinum metals, and an old-established family business in Pforzheim-Dr Richter and $\mathrm{Co}$-was acquired, the Pforzheim plant remaining today as the most important branch in the production of gold alloys. Later the business of G. Siebert-for long a specialised refiner and fabricator of gold and platinum metals in Hanau-was also absorbed.

In 1928 it seemed to the then directors that the rather long and complicated name under which they traded-Die Deutsche Gold-und Silber-Scheideanstalt vormals Roessler-could with advantage be simplified, and it was then that the present name of Degussa was coined.

Progress continued smoothly in the thirties, only to be disastrously interrupted by the destruction of most of the major works, laboratories and offices in the latter part of World War II, and yet again the difficulties of a new beginning had to be faced. The story of the painful step-by-step reconstruction and renewed expansion is inseparably associated with the name of Hermann Schlosser, who had succeeded Dr Busemann as chairman of the board on the latter's death in 1939 . New plants were erected, first for the production of cyanides, of fillers for the rubber and plastics industries, of 
pigments and of pharmaceuticals, while in 1955 an important step was taken in entering the nuclear energy field with the production of fuel elements.

Similarly the metallurgical activities were revived at Hanau and Pforzheim, and Degussa again took its place as one of the leading refiners and fabricators of gold, silver and the platinum metals under the guidance of Robert Hirtes and of Dr Ulrich Hoffmann and later of Erich Furler and Dr Hellmuth Schmidt.

In the field of research many contributions have been made to the knowledge of gold, silver and the platinum metals and their alloys-and of their applications in industry-under the leadership successively of Dr Alfred Boettcher, Dr Carl
Froehlich and Dr Otto Loebich. More recently, on a new site at Wolfgang near Frankfurt, a modern and well equipped laboratory for metallurgical research has been built, alongside a chemical research facility erected a little earlier, with the expressed intention of encouraging the interplay of ideas between chemists, physicists and metallurgists and the development of new types of industrial materials.

The centenary celebrations held in Frankfurt formed one of the last occasions on which the chairman, Dr Felix Prentzel, was to preside. After a long and distinguished period in this office, including the supervision of the more recent expansion programme, he is shortly to be succeeded by Mr Paul Ungerer.

\section{The Sources and Composition of Prehistoric Gold}

\section{INVESTIGATIONS BY EMISSION SPECTROSCOPY}

Since 1950 systematic investigations into prehistoric metallurgy have been carried out by the Arbeitsgemeinschaft für Metallurgie des Altertums bei dem Römisch-Germanischen Zentralmuseum at Mainz and most interesting results have emerged from the cooperation of chemists and archaeologists. Some 3,300 gold objects have now been studied by emission spectroscopy, and a review of the findings is given in a paper by A. Hartmann and E. Sangmeister (Angew. Chem., 1972, 84, (14), 668).

The objects come from hoards found all over Europe, from Spain and Ireland to Denmark and the Danube basin. Also included in the programme of analysis were samples of gold from European ore deposits in the hope that these might reveal where the gold was mined in prehistoric times. An initial examination of the gold ores showed that tin and platinum occur typically as minor impurities in secondary (alluvial) gold deposits but not in primary (mined) gold. This is due to the tendency of heavy minerals, such as native platinum and cassiterite, to concentrate with the gold during washing. Thus we have a simple means of checking the type of gold used for the prehistoric objects, since we can be sure that no refining process was used.

The analyses of the gold objects shows that from the Early Bronze Age to the Roman era almost all the objects were made from alluvial gold because of the invariable presence of tin. It can be inferred that primary gold ores were not worked systematically until well into Roman times. However, rather surprisingly, some of the earliest samples coming from the Copper Age and Early Bronze Age were of metal that did not contain tin. This metal has been identified as Gold $B$, and three explanations of its source are possible. First, the metal could have come from hand-picked nuggets which would be free of other minerals. Secondly, a source of tin-free alluvial gold might have existed that is now exhausted. Thirdly, the gold could have been imported from an area where mining was already established. Evaluation of the other minor constituents of these samples shows that they probably came from the Near East where, particularly in Egypt, gold mining was well established by 3000 B.c. The distribution map of the finds of Gold B shows mostly coastal sites which fit in with the possibility of sea trade links with the Eastern Mediterranean.

In the Early Bronze Age, Gold B, which normally contains less than 10 per cent silver, is replaced by an alloy containing, on average, 26 per cent silver. This alloy is known as Gold A3 and is alluvial in origin. Most of the finds of Gold A3 are concentrated in the middle Danube area. Primary gold ores found in this region near Brad in Romania are very similar in composition to Gold A3. These deposits can be assumed to be the source of the secondary deposits used in the Bronze Age which are now worked out. The gold from this area was exported as widely as Scandinavia, the Netherlands and possibly Brittany. It is hoped that further work will reveal whether it was also supplied to Mycenae, Troy and the Hittite Empire.

At the beginning of the second millenium B.C. a third type of metal, Gold $N$, alluvial in nature, with a rather higher than normal copper content of 2 per cent, was introduced. The source of this metal is not known although a large number of objects were made from it. It is possible that a rather rich mine existed in Eastern Europe but with the present international tensions this cannot be checked.

The distribution of the objects made from Gold $\mathrm{N}$, which are mostly found in Central and Northern Europe, Spain and the British Isles, is probably related to the westward migration of races from Eastern and Central Europe that is known to have occurred at this time.

By about 1000 B.C. up to 10 per cent copper was being intentionally added to Gold $N$, producing a warm coloured and somewhat harder alloy. This process was established first in the British Isles and only later in the rest of Europe. The reason for this is not fully understood.

Ch. J. R. 